\title{
EFEKTIFITAS KONSELING EKLEKTIF DENGAN PERILAKU ATTENDING UNTUK MENGURANGI MASALAH BELAJAR SISWA KELAS IX DI SMP BILINGUAL TERPADU KRIAN SIDOARJO
}

\author{
Trisno \\ SMP Bilingual Terpadu Krian Sidoarjo \\ trisno@smpbilingualterpadu.sch.id
}

\begin{abstract}
This research is a research type of Counseling Guidance Action. This research raises about eclective counseling by attending and students learning problems. The purpose of this study was to determine the effectiveness of eclectic counseling with attending behavior to reduce learning problems for class IX students of SMP Bilingual Terpadu Krian Sidoarjo. The research method used in analyzing the data in this study is qualitative. The research process took place in two cycles, namely cycle I and cycle II. Cycle $I$ is the stage where the treatment is first carried out after conducting an assessment and preparation of an action plan. Cycle II is a follow-up action taken after cycle $\mathrm{I}$ is deemed less than optimal, therefore the researcher designed and implemented cycle II. The research subjects were students of class IX in the 2020/2021 academic year who after initial observations were taken 3 people who have a level of learning problems that are considered the highest of other students. Data collection techniques used interviews and observation through group counseling. In this research it was found that there were significant changes in the problems the students faced tended to improve. With the results of the first cycle of 46 (low) and the results of the second cycle of 68.33 (moderate). Based on this research, it can be concluded that the effectiveness of exclusive counseling with attending behavior to reduce the learning problems of class IX students of SMP Bilingual Terpadu.
\end{abstract}

\section{ABSTRAK}

Penelitian ini adalah jenis penelitian Tindakan Bimbingan Konseling. Penelitian ini mengangkat tentang konseling eklektif dengan attending dan permasalahan belajara siswa. Tujuan penelitian ini adalah untuk mengetahui efektifitas konseling eklektif dengan perilaku attending untuk mengurangi masalah belajar siswa kelas IX SMP Bilingual Terpadu Krian Sidoarjo. Metode penelitian yang digunakan dalam menganalisis data dalam penelitian ini adalah kualitatif. Proses penelitian ini berlangsung dua siklus yaitu siklus I dan siklus II. Siklus I merupakan tahapan dimana pemberian treatmen pertama kali dilakukan setelah melakukan assesmen dan penyusunan rencana tindakan. Siklus II merupakan tindakan lanjutan yang dilakukan setelah siklus I dirasa kurang maksimal, maka dari itu peneliti merancang dan melaksanakan siklus II. Subjek penelitian adalah siswa kelas IX tahun pelajaran 2020/2021 yang setelah dilakukan observasi awal diambil 3 orang yang memiliki tingkat permasalahan belajar yang dianggap paling tinggi dari siswa lainnya. Teknik pengambilan data memakai wawancara dan observasi melalui konseling kelompok. Dalam riset ini ditemukan bahwa terjadi perubahan yang signifikan pada masalah siswa yang dihadapi cenderung membaik. Dengan hasil siklus I sebesar 46 (rendah) dan hasil pada siklus II sebesar 68,33 (sedang) Berdasarkan penelitian ini, maka dapat disimpulkan bahwa efektifitas konseling eklektif dengan perilaku attending untuk mengurangi masalah belajar siswa kelas IX SMP Bilingual Terpadu.

Kata Kunci konseling eklektif, attending, masalah belajar 
Trisno

Efektifitas Konseling Eklektif dengan Perilaku Attending untuk Mengurangi Masalah Belajar Siswa Kelas IX...

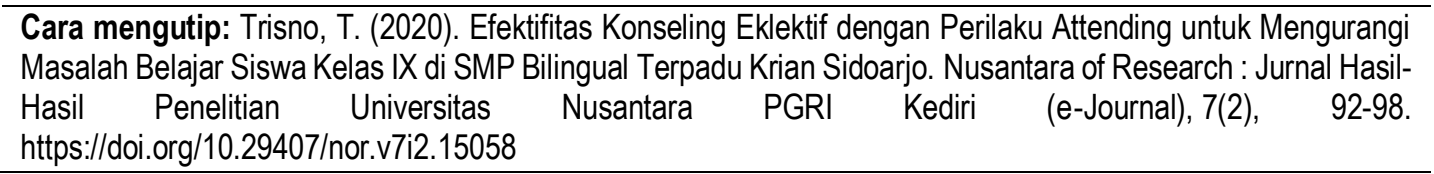

\section{PENDAHULUAN}

Pendidikan termasuk salah satu investasi kehidupan yang penting dan berharga. Karena dengan pendidikanlah cara terbaik meningkatkan mutu Sumber Daya Manusia (SDM) yang berkualitas, mempunyai karakter yang tangguh dan siap bersaing di perkembangan jaman yang sudah sangat maju ini hal itu dapat dicapai jika proses pendidikan berjalan dengan baik. Hal tersebut seperti apa yang terdapat pada UU No. 20 Tahun 2003 tentang system pendidikan nasional, usaha terencana dan sadar untuk mewujudkan dan menyiapkan peserta didik dapat secara aktif menegembangkan potensi melalui kegiatan pembelajaran, bimbingan, dan latihan guna meyiapkan perannya dimasa depan.

Dalam perkembangan pendidikan terutama di masa pandemi seperti ini permasalahan yang dihadapi oleh siswa sangat beragam antara permasalahan pribadi dan sosial, masalah karakter dan kedisiplinan. Khususnya permasalahan belajar sangat sering dialami oleh siswa. Misalkan yang peneliti temukan ditempat peneliti mengajar sering terjadi permasalahan belajar seperti siswa ramai saat pembelajaran, siswa tidak berani meyampaikan pendapat atau bertanya. Ketidak hadiran dalam mengikuti pelajaran tertentu lumayan tinggi. Dari hal tersebut peneliti sebagai guru bimbingan konseling tertarik untuk meneliti permasalahan tersebut. Hal tersebut sejalan dengan penelitian yang pernah dilakukan oleh Bani Suti Nasution (2017) yang berjudul mengatasi permasalahan belajar siswa melalui konseling eklektif dengan perilaku attending pada siswa kelas IX-B SMP Negeri 3 Panyambungan. Dari penelitian tersebut diperoleh hasil bahwa konseling eklektif mampu mengurangi masalah belajar yang sedang dihadapi oleh siswa (konseli).

Sedangkan definisi masalah dalam KKBI (2016) adalah suatu yang harus diselesaikan atau dicari jalan keluarnya. Subini (2013) suatu keadaan dimana kemempuan dan prestasi yang di capai tidak sama dengan standart minimal yang telah ditentukan. Sedangkan dalam psikologi, arti dari belajar adalah proses berubahnya tingkah laku yang dihasilkan dari berinteraksi dengan lingkungan sekitar untuk memenuhi kebutuhannya. Aunurahman (2016) Belajar dapat diartikan juga sebagai proses yang dialami seseorang untuk mendapatkan suatu pembaharuan tingkah laku yang baru, sebagai hasil dari pengalaman yang telah dialami seseorang itu sendiri dalam berionteraksi terhadap lingkungan. Dari definisi di atas maka dapat dikatakan masalah belajar adalah keadaan tertentu yang dialamai oleh siswa atau konseli yang menghalangi proses yang dilakukan siswa atau konseli dalam mendapatkan perubahan tingkah laku baru.

Bimbingan konseling ada di lingkungan pendidikan ternyata membawa manfaat yang amat besar untuk perkembangan pendidikan di Indonesia khususnya untuk perkembangan pribadi siswa. Trisnayadi (2013) hampir dapat dipastikan hambatan selalu ada disetiap perjalanan proses belajar. Kesulitan dan gangguan baik kecil maupun besar tentu saja bisa datang dari diri sendiri dan dari luar. Misalkan 1) rasa malas, 2) sulit menyerap pembelajaran, 
3) sulit konsentrasi, 4) kenakalan remaja, 5) motivasi belajar rendah. Dalam kenyataannya penyelesaian masalah tersebut menurut bimbingan konseling bisa dilakukan melalui bermacam-macam cara melaui bimbingan kelompok atau konseling. Konseling kelompok sendiri berasal dari dua kata konseling dan kelompok. Konseling sendiri menurut Ahmadi dan Widodo (2012) memiliki arti pemberian nasehat, saran, dan komunikasi dengan bertukar pikiran. Konseling kelompok sendiri memiliki arti model konseling dengan memanfaatkan dinamika kelompok untuk memberi saran, memberi nasehat, pengalaman belajar dan menggunakan prisnsip dinamika kelompok.

Penelitian ini menggunakan konseling eklektif merupakan konseling yang menggunakan teori yang dipilih dari beberapa pendekatan yang baik dan cocok dari berbagai jenis teori, metode dan pengalaman praktik yang digunakan bersama-sama dalam membatu siswa saat konseling. Perilaku attending itu bisa dikatakan salah satu teknik menghadapi konseli dengan menggunakan kontak mata, gestur tubuh, Bahasa lisan, sehinga membuat konseli terlibat pembicaraan terbuka. Attending ini sangat baik untuk menigkatkan harga diri konseli. Attending ini erat kaitannya dengan teknik penerimaan konselor terhadap konseli, sehingga konseli merasa sangat dihargai. Melalui konseling eklektif attending berorientasi pada berubahnya tingkah laku secara nyata, secara tidak langsung memberikan sumbangsih atas keberhasilan konseli di rumah maupun di sekolah.

\section{METODE}

Dalam penelitian ini data dianalisis menggunakan metode kualitatif, menurut Saryono (2010) kualitatif adalah penelitian yang dipakai untuk menjelaskan keistimewaan dari pengaruh social yang tidak dapat dijelaskan atau diukur dengan pendekatan kuantitatif. Sedangkan teknik pengumpulan data yang digunakan adalah observasi dan wawancara akan tetapi ketika melakukan analisis, pengolahan data tidak terletak pada suatu garis lurus secara terus menerus ketika hasil data terkumpul semua, tetapi akan dilakukan dengan cara bertahap saat proses pengumpulan data dan dilakukan saat data terkumpul semua. Dengan seperti itu akan terjadilah hubungan antara proses dan analisis data beserta unsur-unsur lain seperti perekaman data, pembuatan laporan, dan memberikan pertanyaan penelitian.

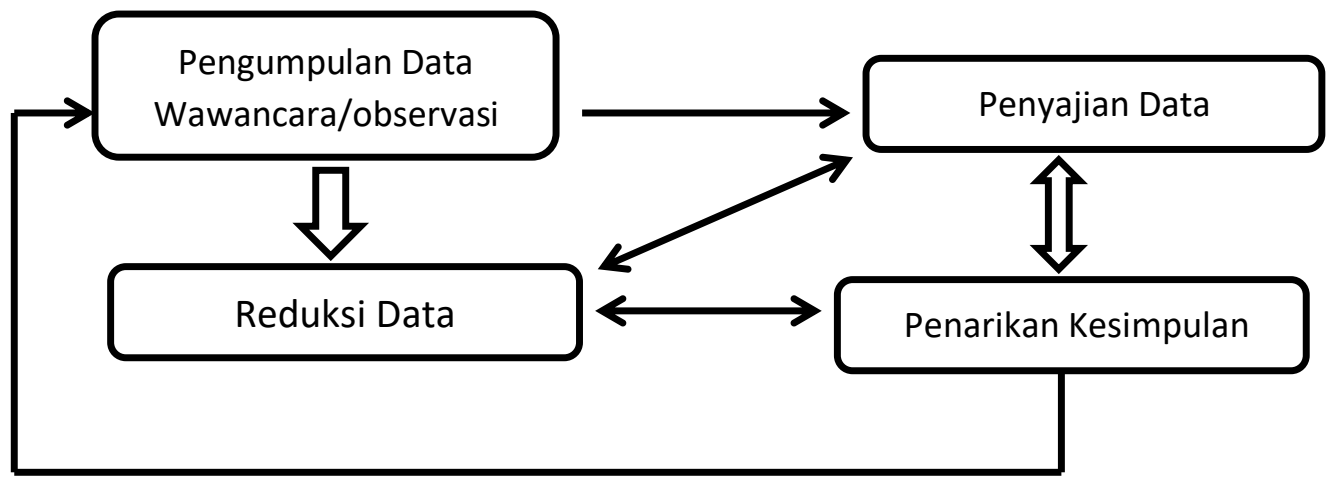

Gambar 1. Teknik Analisis Data

Hubungan dari bermacam-macam unsur tersebut membentuk pola siklus. Selanjutnya hasil data yang didapat pada siklus I dan II dilakukan perbandingan kemudian 
Trisno

Efektifitas Konseling Eklektif dengan Perilaku Attending untuk Mengurangi Masalah Belajar Siswa Kelas IX...

dijabarkan kedalam bentuk kalimat. Bahkan untuk meningkatkan reflesitivitas ketika pengumpulan data, konselor sebagai peneliti menggunakan banyak cara; 1) memberikan kritik dan pertanyaan tentang proses penelitian berlangsung, 2) melakukan konfirmasi seperti wawancara, kelompok utama, 3) megelompokan, memberitanda, mengolah catatan, 4) mencatat perbedaan etika, tindakan serta keutusan, 5) mencatat kejadian harian yang memuat banyak hal berhubungan dengan penelitian, 6) bekerja sama dengan teman yang mampu meringankan proses peniltian dari awal sampai selesai.

Hasil pengumpulan data, pemeriksaan data yang didapat oleh peneliti melalui pengamatan pada siklus I dan siklus II selanjutnya digunakan peneliti untuk mengambil sebuah kesimpulan bahwa teknik konseling eklektif melalui attending dinyatakan efektif dalam mengurangi masalah belajar siswa.

\section{HASIL}

Peneliti selaku konselor menyusun rencana penelitian dalam layanan konseling kelompok kepada tiga orang siswa yang mempunyai karakter permasalahan yang sama yaitu masalah belajar melalui Teknik Eklektif dalam perilaku attending. Data yang diperoleh dari observasi kepribadian siswa, diperoleh penjelasan bahwa ada 3 siswa yang kurang atau bisa dikatakan memiliki permalahan belajar yang tinggi. Dari observasi awal diperoleh data sebagai berikut:

\section{Tabel 1. Hasil Observasi awal Kepribadian siswa}

\begin{tabular}{clccccccccccc}
\hline No & Nama Siswa & 1 & 2 & 3 & 4 & 5 & 6 & 7 & 8 & 9 & 10 & Jumlah \\
\hline 1 & IB & 1 & 1 & 1 & 1 & 1 & 1 & 2 & 1 & 2 & 1 & $12=30$ \\
2 & AL & 1 & 1 & 1 & 2 & 1 & 1 & 1 & 1 & 1 & 2 & $12=30$ \\
3 & FH & 2 & 1 & 1 & 2 & 1 & 2 & 2 & 2 & 2 & 2 & $17=42,5$ \\
\hline & JUMLAH & 4 & 3 & 3 & 4 & 3 & 4 & 4 & 4 & 4 & 4 & 41 \\
\hline & PREDIKAT & $41: 12 \times 10=34,16$ Kurang & & & & & \\
\hline
\end{tabular}

Dari hasil observasi awal di atas menunjukan gambaran keadaan keperibadian 3 siswa atau konseli di SMP Bilingual Terpadu yang masih sering ramai saat pembelajaran, masih belum berani berpendapat dan bertanya, belum bias berkata jujur. Dari hasil observasi tersebut peneliti merancang pemberian treatment pada siklus I. setelah pemberian treatment di siklus I diperoleh data seperti berikut:

Table 2. Hasil Siklus I

\begin{tabular}{lllllllllllll}
\hline No & Nama & 1 & 2 & 3 & 4 & 5 & 6 & 7 & 8 & 9 & 10 & JML \\
\hline 1 & IB & 1 & 1 & 1 & 1 & 1 & 1 & 2 & 1 & 2 & 2 & $13=33$ \\
2 & AL & 1 & 1 & 1 & 1 & 1 & 2 & 1 & 2 & 2 & 2 & $14=35$ \\
3 & FH & 3 & 3 & 3 & 3 & 1 & 3 & 3 & 3 & 3 & 3 & $30=75$ \\
\hline & JUMLAH & 5 & 5 & 5 & 5 & 3 & 6 & 6 & 6 & 7 & 7 & 55 \\
\hline & PREDIKAT & $55: 12 \times 10=46$ & Kurang & & & & & &
\end{tabular}

Berdasarkan hasil dari pemberian treatment pada siklus I belum menunjukan perkembangan yang signifikan yaitu di score 46 (Kurang), hal tersebut ditunjukan dengan masih adanya indicator siswa masih ramai saat proses pembelajaran, masih belum berani untuk 
bertanya dan berpendapat, belum bisa berkata jujur. Maka dari itu peneliti memutuskan untuk merancang dan melakukan perbaikan di siklus II. Dari pelaksanaan treatment di siklus II diperoleh hasil sebagai berikut:

Table 3. Hasil Siklus II

\begin{tabular}{clccccccccccl}
\hline No & Nama & 1 & 2 & 3 & 4 & 5 & 6 & 7 & 8 & 9 & 10 & JML \\
\hline 1 & IB & 3 & 2 & 2 & 3 & 2 & 3 & 2 & 2 & 2 & 3 & $24=60$ \\
2 & AL & 2 & 2 & 2 & 2 & 3 & 2 & 2 & 3 & 2 & 3 & $23=58$ \\
3 & FH & 3 & 3 & 3 & 3 & 3 & 4 & 4 & 4 & 4 & 4 & $35=88$ \\
\hline & JUMLAH & 8 & 7 & 7 & 8 & 8 & 9 & 8 & 9 & 8 & 10 & 82 \\
\hline & PREDIKAT & $82: 12 \times 10=68,33$ Sedang & & & & & \\
\hline
\end{tabular}

Dari pemberian treatment di siklus II diperoleh hasil data seperti di atas, dari data tersebut sudah menunjukan perkembangan kepribadian siswa atau konseli yaitu diangka 68,33 (sedang). Dari hasil bagus tersebut peneliti berfikir penelitian dihentikan sampai disini. Maka dari itu penelitian tidak perlu dilanjutkan ke siklus berikutnya.

\section{PEMBAHASAN}

Pada penelitian ini peneliti memilih pendekatan teori behavioristik, karena behavioristik lebih berfokus pada tingkah laku manusia. Behavior menganggap manusia sebagai individu yang reaktif yang senantiasa merespon lingkungan. Keahlian dan perawatan akan mencetak sebuah perilaku dari mereka. Karakter dari behavioristik lebih menekankan pada bagian-bagian kecil, sesuai prosedur, mengutamakan peran dari lingkungan, pentingnya pembentukan respon, dan pentingnya berlatih. Maka dari itu bisa dikatakan perilaku belajar adanya hubungan erat antara reaksi dan perilaku. Penjelasan di atas didukung hasil penelitian serupa yang dilakukan oleh Sukri (2018) dengan judul penerapan konseling eklektif dengan perilaku attending untuk mengatasi masalah dan meningkatkan prestasi belajar siswa dapat disimpulkan bahwa penggunaan teknik tersebut terbukti efektif untuk menurunkan dan mengatasi masalah belajar yang muncul dan dialami oleh siswa.

Sampel yang diambil dalam penelitian tindakan kelas ini adalah 3 orang siswa dikelas IX SMP Bilingual Terpadu, dengan taraf maslah belajar mereka yang cenderung tinggi, ke tiga anak ini termasuk banyak pelanggran saat proses belajar seperti terlambat masuk kelas, sering tidak mengerjakan tugas, banyak keluhan dari guru anak tersebut sering ramai, sering tidur dan malas saaat guru ada di kelas. Tempat penelitian tersebut dilakukan di SMP Bilingual Terpadu Krian Sidoarjo.

Pelaksanaan riset ini diawali dengan melakukan observasi tahap awal dan dipeorlah hasil 36,16 (kurang). Dari hasil nilai tersebut diperoleh gambaran kepribadian siswa sebagai berikut. 1) siswa masih sering ramai ketika proses pembelajaran, 2) siswa masih belum berani berpendapat dan bertanya, 3) siswa belum berani berkata jujur. Karena hal tersebut peneliti menyusun tahapan selanjutnya. Tahapan tersebut dilakukan secara daring dan luring dengan 2 siklus. Pada siklus I dilakukan secara luring terdiri dari lima tahap yaitu Merencanakan, penerapan/implementasi, pengamatan, evaluasi serta refleksi. Dari pemberian treatmen disiklus I memperoleh hasil seperti yang ditunjukan pada tabel $1.1 \mathrm{di}$ atas. Setelah siklus I 
memperoleh hasil, hasil tersebut masih dirasa rendah oleh peneliti karena nilai rata-rata 46 Masih dalam kategori Kurang. Hal tersebut ditandai dengan indikator siswa Kemudian peneliti memutuskan dan merencanakan untuk melakukan siklus II. Karena banyaknya evaluasi disiklus I peneliti memutuskan melakukan siklus II ini secara daring dengan terdiri dari lima tahapan seperti di siklus I. akan tetapi di siklus II jauh lebih di detailkan lagi. Siklus II ini dilakukan secara daring Karena mempertimbangkan masukan dari konseli atau siswa yang menginginkan pelaksanaan konseling secara daring. Dari pelaksanaan konseling secara daring di siklus II memperoleh hasil rata-rata siswa 68,66 seperti yang ditunjukan di table 1.2 di atas. Dari hasil pelaksanaan siklus I dan siklus II, hasil data digunakan oleh peneliti untuk melakukan analisis. Dari data tersbut peneliti melakukan analisis data atau membandingkan hasil data siklus I dan siklus II. Penyajian perbandingan data yang dimaksut sebagai berikut:

Tabel 4. Perkembangan Kepribadian Siswa Siklus I dan Siklus II

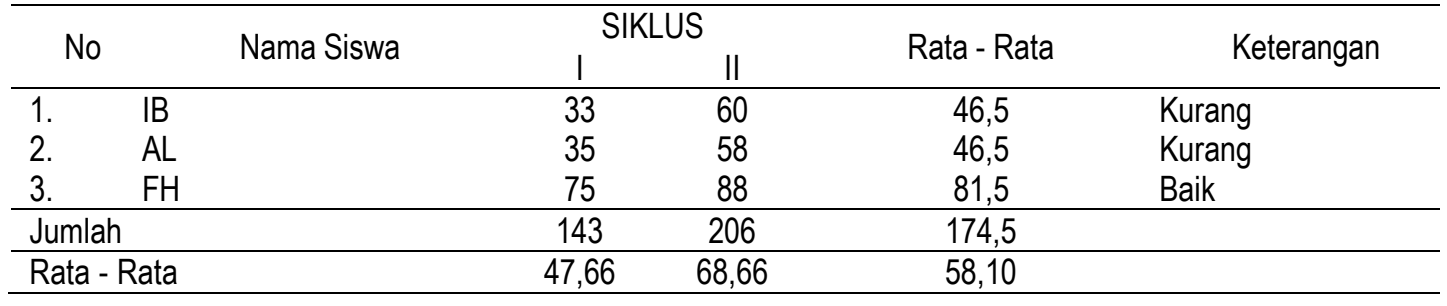

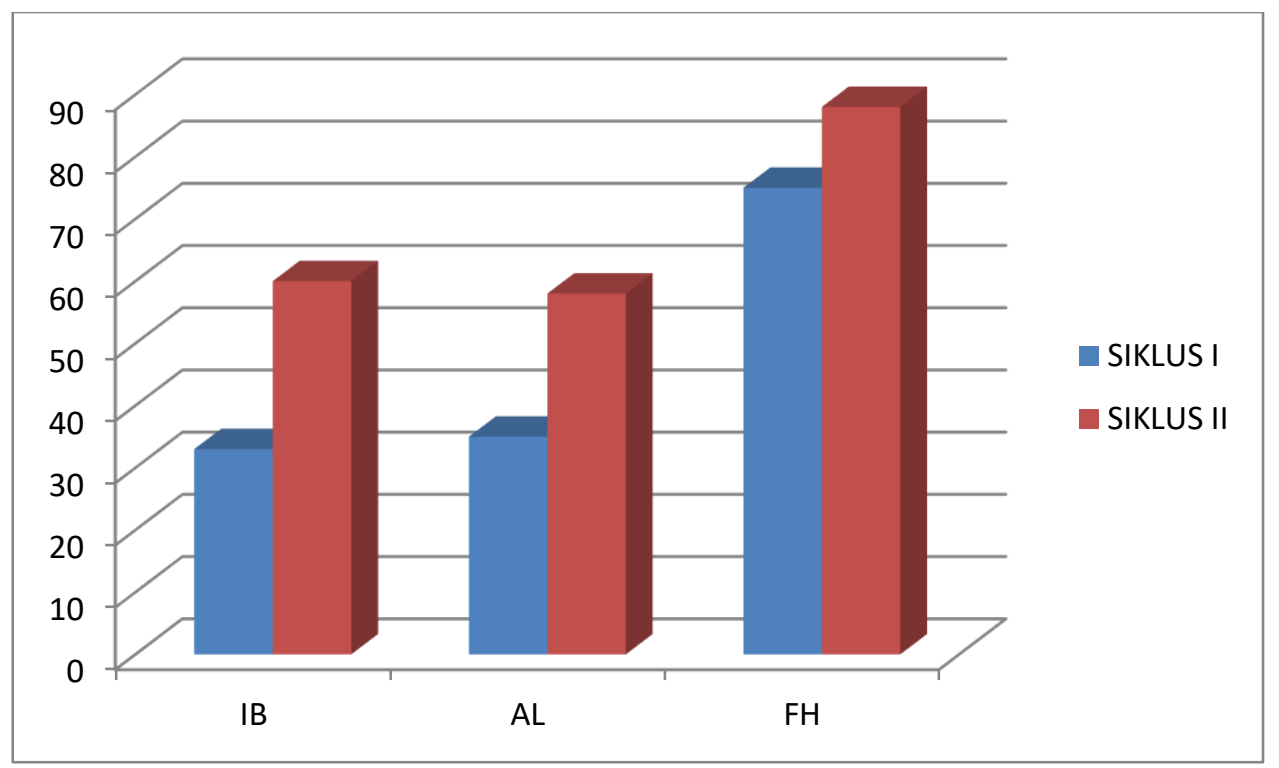

Gambar 2. Grafik perbandingan siklus I dan Siklus II

Dari hasil analisis data di atas tentang perkembangan keadaan konseli pada siklus I dan siklus II setelah dilakukan treatment dan dilakukan perbandingan antara siklus tersebut mengalami peningkatan atau perubahan yang cukup signifikan yaitu hasil disiklus I di angka 47,66 sedangkan hasil disiklus II di angka 68,66 dengan nilai total 174,50 sedangkan nilai ratarata konseli adalah 58,10. Hal tersebut didukung dengan gambaran grafik data yang menunjukan perubahan yang cukup bagus dari tiap-tiap siswa atau konseli. Dari hasil tersebut bisa dikatakan penggunaan konseling eklektif attending dengan konseling kelompok sangat efektif untuk mengurangi atau menurunkan masalah belajar yang sedang dialami oleh konseli atau siswa. Tentunya pemberian treatment masih bisa dilakukan secara berkala kepada siswa 
yang bersangkutan. Karena hasil masih menunjukan taraf sedang sehingga masih memungkinkan untuk menurun kembali.

\section{KESIMPULAN DAN SARAN}

Dari hasil pemaparan dan penjelasan penelitian bimbingan dan konseling yang sudah dilakukan maka penulis mengambil kesimpulan bahwa pendekatan konseling eklektif dalam perilaku attending sangat efektif untuk mengurangi masalah belajar yang dialami konseli. Tentunya hasil dari penelitian ini masih sangat jauh dari kata sempurna maka dari itu saran untuk semua pihak adalah terus mengembangkan dan mengupdate kemampuan dalam melakukan dan menggunakan teknik dan teori konseling dalam membantu menyelsaikan masalah konseli atau siswa. pemberian treatment masih bias dilakukan secara berkala kepada siswa yang bersangkutan. Karena hasil masih menunjukan taraf sedang sehingga masih memungkinkan untuk menurun kembali.

\section{DAFTAR RUJUKAN}

Abu, Ahmadi dan Supriyono, Widodo. 2012. Psikologi Belajar. Jakarta: Rineka Cipta.

Abin Syamsudin, M. 2012. Psikologi Pendidikan Perangkat Sistem Pengajaran Pendidikan. Bandung: PT Remaja Rosdakarya.

Aunurrahman. 2016. Belajar dan Pembelajaran. Bandung: Alfabeta.

Depdiknas. 2003. Undang-Undang Sistem Pendidikan Nasional No. 20 Tahun 2003. Jakarta : Depdiknas.

Ini tentang Psikologi Pendekatan Konseling Eklektif. 2020. (online). (https://www.initentangpsikologi.com/2020/01/pendekatan-konseling-eklektik.html). Diakses pada 19 September 2020.

KBBI. 2016. Kamus Besar Bahasa Indonesia. (Online). Tersedia di (https://kbbi.web.id/masalah). Di akses pada 19 September 2020.

Konseling, Siska. 2015. Teknik Konseling Perilaku Attending. (online).

(https://siskacounseling.wordpress.com/teknik-konseling/2-perilaku-attending/). Diakses pada 19 September 2020.

Sayono. 2010. Metodologi Penelitian Kualitatif. Bandung: Alfabeta.

Subini, N. dkk. 2013. Psikologi Pembelajaran. Yogyakarta: Mentari Pustaka.

Tuwuh, Trisnayadi. 2013. Bimbingan Karier untuk Pelajar Muslim. Jakarta: Erlangga. 